\title{
Application of geostatistical techniques in the assessment of groundwater contamination in the Afigya Kwabre District of Ghana
}

\author{
Victor Ofori Agyemang ${ }^{1}[$
}

Received: 10 June 2020 / Accepted: 26 January 2022 / Published online: 21 February 2022

(c) The Author(s) 2022

\begin{abstract}
Geostatistical techniques have been applied to successfully assess the groundwater quality in the Afigya Kwabre District of Ghana. Forty boreholes were sampled for physicochemical and bacteriological characteristics of the groundwater. Principal component analysis revealed that seven components contain $81.01 \%$ of the variation of the original variables. Factor 1 accounted for $31.34 \%$ of the total variance, factor 2 accounted for $10.97 \%$, third and fourth factors explained $8.41 \%$ and $8.19 \%$, the fifth factor showed $8.13 \%$ while the sixth and seventh components showed $7.76 \%$ and $6.21 \%$ variances, respectively. R-mode cluster analysis showed five clusters. Cluster 1 was made of $\mathrm{Na}^{+}, \mathrm{Cl}^{-}, \mathrm{TH}, \mathrm{SiO}_{2}, \mathrm{HCO}_{3}{ }^{-}$and TDS. Cluster 2 and cluster 3 contained dissolved oxygen (DO), $\mathrm{pH}, \mathrm{K}^{+}$and $\mathrm{F}^{-}$, Br, respectively. Cluster 4 was made of $\mathrm{PO}_{4}{ }^{3-}$ and $\mathrm{NO}_{3}{ }^{-}$and Cluster 5 had $\mathrm{Ca}^{2+}, \mathrm{Mg}^{2+}$, Total. coli, Fecal. coli, $\mathrm{SO}_{4}{ }^{2-}$, and salinity. Correlation analysis revealed a strong positive correlation between EC and TDS, $\mathrm{Mg}^{2+}, \mathrm{Ca}^{2+}, \mathrm{Mn}, \mathrm{Na}^{+}, \mathrm{TH}, \mathrm{HCO}_{3}^{-} ; \mathrm{pH}$ and $\mathrm{Ca}^{2+}, \mathrm{HCO}_{3}^{-} ; \mathrm{Mg}^{2+}$ and $\mathrm{Ca}^{2+}, \mathrm{Na}^{+}, \mathrm{TH}, \mathrm{HCO}_{3}^{-}$, $\mathrm{Fe} ; \mathrm{Ca}^{2+}$ and $\mathrm{Na}^{+}$, $\mathrm{TH}, \mathrm{HCO}_{3}{ }^{-} ; \mathrm{Cu}$ and $\mathrm{PO}_{4}{ }^{3-} ; \mathrm{Mn}$ and $\mathrm{Na}^{+} ; \mathrm{F}^{-}$and $\mathrm{SO}_{4}{ }^{2-}$ as well as $\mathrm{NO}_{3}{ }^{-}$and $\mathrm{PO}_{4}{ }^{3-}$. The study revealed the impact of both natural processes such as rock mineral weathering, ion exchange, and anthropogenic activities such as application of agrochemicals on farmlands and improper waste disposal on the geochemistry of the groundwater. Generally, the groundwater in the District has a low $\mathrm{pH}$. However, it is generally suitable for domestic use with exception of a few samples with high $\mathrm{Fe}, \mathrm{F}-, \mathrm{Pb}$ concentrations and Escherichia coliform and fecal coliform contaminations. The study has shown that the geostatistical technique is useful in determining the state of water contamination, the extent of contamination, and possible source of contaminants, as well as presenting a guideline for effective groundwater resource management.
\end{abstract}

Keywords Geostatistical techniques · Groundwater · Afigya Kwabre District · Principal component analysis · Cluster analysis

\section{Introduction}

Water is one of the essential natural resources in the human environment; hence, the quantity and the quality of available water is very important as clean drinking water promotes good hygiene and improved health (Raju 2007). Activities such as navigation, transportation, hydroelectric power generation, and agricultural activities depend on water and in areas where surface water is scarce, some of these activities depend heavily on groundwater resources (Sakyi 2016). Therefore, the effective management of groundwater resources plays an important role in national development.

Victor Ofori Agyemang

oforiagyemangvictor@yahoo.com

1 Community Water and Sanitation Agency, Hydrogeological Unit, P. O. Box 1315, Cape Coast, Ghana
Nowadays, there is a high demand for groundwater resources due to the high population growth rate, its availability, deteriorating quality of surface water, etc. According to NGWA (2016), the estimated rate of groundwater extraction around the world is $982 \mathrm{~km} 3 /$ year. The report suggests that about $60 \%$ of groundwater extracted globally is used for agriculture and the remaining $40 \%$ is used for domestic and industrial purposes. In Ghana, people depend on groundwater for drinking, domestic, agriculture, etc. and the major means of taking groundwater are boreholes, hand-dug wells, and dugouts (Kortatsi 2009). In rural communities and small towns, groundwater is mainly used for domestic purposes since Ghana Water Company Limited does not serve those communities with treated water and the surface water bodies are contaminated (CWSA 2018). Therefore, there is always an increasing demand for groundwater resources with increasing population size. 
Traditionally, groundwater quality study has been the investigation of a certain parameter in the laboratory; however, the application of Geographic Information System (GIS) nowadays makes it possible to integrate different information for effective assessment. The application of GIS enhances the storage, analysis, spatial display of data, and decision-making processes (Fadhillah et al. 2021). In a GIS framework, point estimates of water quality parameters can be spatially interpolated by spatial interpolation techniques such as kriging, inverse distance weighting to develop parameter concentration maps at different time scales or related maps. The use of GIS bridges the communication gap between researchers and other stakeholders (Fadhillah et al. 2021).

In groundwater studies, it is important to combine, assemble, present, and properly interpret the data for easy examination (Fadhillah et al. 2021). Different techniques used in groundwater studies include graphical techniques, statistical techniques, remote sensing (RS), GIS and geostatistical techniques, and modeling techniques. The quantitative analysis of groundwater relative to other samples or some standards is done by applying statistical techniques. The changes in groundwater quality with time and space can be shown by time series plots displayed by scattering, line, areal or bar diagrams to monitor the changes in concentration of the various parameter with time. A correlation matrix analysis is a bivariate method, which shows how well one variable predicts the other and reveals the possible source and pathway of parameters. Hierarchical cluster analysis (HCA) and factor analysis (FA) techniques reveal the possible processes that affect the quality of the groundwater based on the elemental associations. Hierarchical cluster analysis is a pattern detection technique that reveals the basic structure of a dataset and groups them into clusters based on similarities (Otto 1998). Clusters are formed successively, starting with a most similar pair of objects and forming higher clusters step by step and the result is displayed as a dendrogram. In Ghana, groundwater quality monitoring has not received the necessary attention it deserves, though most of the rural communities depend on it for all their water needs, hence, over the years, Ghana has experienced the outbreak of diseases such as cholera and dysentery due to contaminated groundwater (Nkrumah 2005).

\section{The study area}

The Afigya Kwabre District is newly created in the Ashanti Region of Ghana bounded by $6^{\circ} 5^{\prime} \mathrm{N} \& 7^{\circ} 1^{\prime} \mathrm{N}$ latitudes and $1^{\circ} 4^{\prime} \mathrm{W} \& 1^{\circ} 25^{\prime} \mathrm{W}$ longitudes. The district has a total land size of 409.4 sq. $\mathrm{km}$ which forms $1.4 \%$ of the total land area of the Ashanti Region (Ghana Statistical Report 2010). The district has an equatorial climate, a minor rainfall period (between September and November), and a major rainfall period (between March and July). The mean annual rainfall ranges between 855 and $1500 \mathrm{~mm}$ and the average number of rainy days for the year is between 110 and 120 days (Yidana et al. 2015). The district has a dissected plateau landscape that forms part of the MampongGambaga scarp with heights between 800 and $1200 \mathrm{~m}$ above sea level. Water flows easily within the area due to its undulating nature. The rivers in the area include Offin, Oyon, and Abankro Rivers. Agriculture is the major occupation of the people in the District. The area has a total cultivated land of about 53,250 hectares beside pastures and forest reserves (Ghana Statistical Services 2010). Food crops cultivated include plantain, cassava, cocoyam, and maize, as well as vegetables such as tomatoes, garden eggs, pepper, and onions are also cultivated. The farmers apply agrochemicals such as weedicides, pesticides, fertilizers, and animal manure on the farmland. The geology of the Afigya Kwabre District is made of the Voltaian Supergroup and granitoids of the Birimian (Fig. 1) both of which hydrogeology are controlled by secondary hydrogeological parameters such as weathering, fractures, and fissures (Yidana et al. 2015). According to Kesse (1985), the pan-African tectonic activities affected the

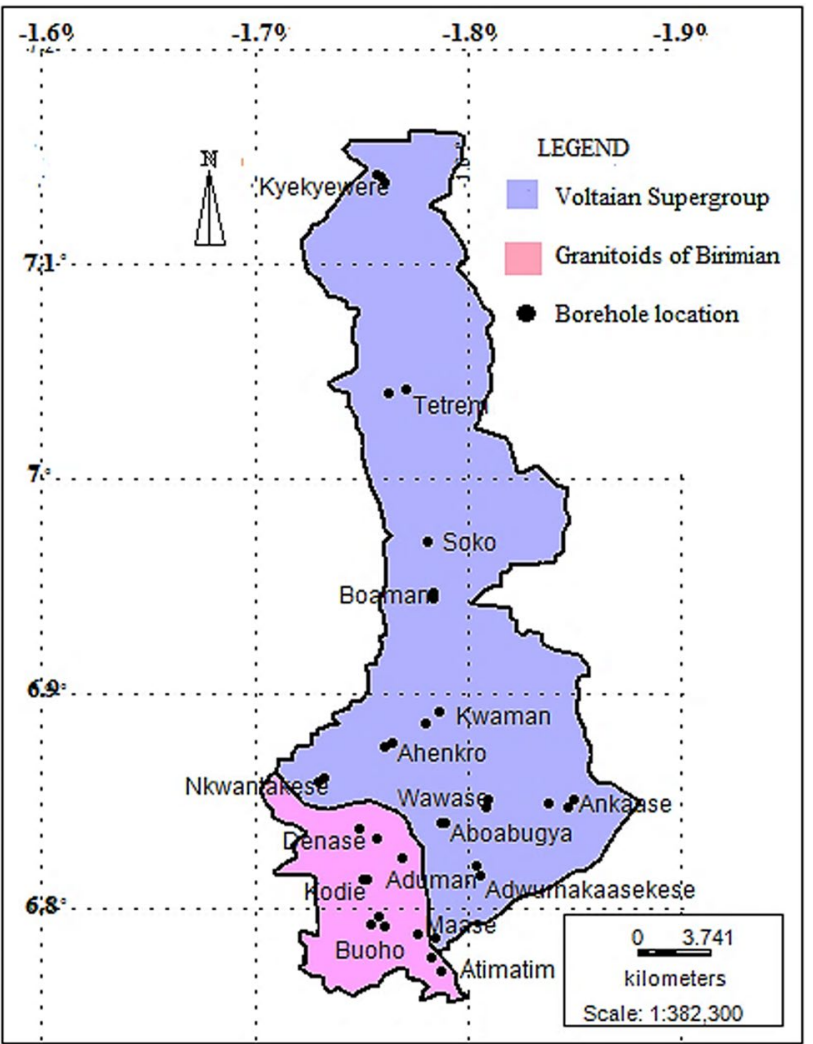

Fig. 1 The Geological map of the Afigya Kwabre District (Agyemang 2019) 
hydrogeological properties of the semi-confined Voltaian sandstone formation. After undergoing partial metamorphism, the formation which is hydrogeologically difficult to study in Ghana had reduced success rates for drilling prolific wells to less than 60\% (Yidana et al. 2015).

When the weathered zone is considerably thick and the clay content is minimal the hydraulic conditions of the rock are very much enhanced and they offer significant quantities of water to wells. The confined Birimian granitoid aquifers belong to the crystalline basement aquifer province where groundwater occurs mainly in the saprolite, saprock and the fractured bedrock and is generally better than the aquifers of the Voltaian (Obuobie et al. 2016). In these rocks, groundwater occurrence is controlled by the nature and thickness of the decomposed zone, rock fracture, joints, quartz veins, and pegmatites and lower part of the saprolite and the upper part of the saprock within the Birimian Province serves as the most productive zones (Yidana et al. 2014). Proterozoic Eburnean orogenic activities caused a brittle deformation which resulted in the fracture and brecciated of the quartz veins and pegmatites (Kesse 1985).

\section{Methodology}

Forty (40) samples were taken from forty active boreholes in September, 2015. The American Public Health Association and WHO regulations and procedures (APHA 1995; WHO 2008) were used during sampling and laboratory analysis. In the laboratory, the probe method was used to measure temperature, $\mathrm{pH}$, conductivity, and TDS. Ion chromatography was used to analyze fluoride, chloride, sulfide, nitrate, bromide, phosphate, carbonate, silicate, and sulfate. Flame Atomic Absorption Spectrometry (AAS) was used to analyze lead, copper, manganese, cadmium, magnesium, calcium, zinc, and iron. The bicarbonate which was expressed in terms of alkalinity $\left(\mathrm{CaCO}_{3} \mathrm{mg} / \mathrm{l}\right)$ was converted into $\mathrm{HCO}_{3}$ - by using the formula proposed by Hem (1985). Total suspended solids (TSS) was analyzed by photometric method 8006 (Non-filterable residue), total hardness (TH) was analyzed by titrimetric method, alkalinity was analyzed by titration method, turbidity was analyzed by absorptiometric method, color was analyzed by cobalt standard method, salinity was analyzed by electrical conductivity method, sodium and potassium were analyzed by flame photometer, biochemical oxygen demand (BOD) and dissolved oxygen (DO) were analyzed by 5-day BOD test and acid modification, respectively. Blind sampling and ionic balance techniques were employed to assess the accuracy of the laboratory results and they all fall within the acceptable range of $\pm 10 \%$ (Celesceri et al. 1998).

\section{Results and discussion}

Table 1 shows the statistical summary of the results of the study, covering the physicochemical and bacteriological characteristics of groundwater in the study area.

\section{Spatial distribution of water quality parameters}

In generation of the various thematic maps, different appropriate radiograms were generated for the various parameters in the processes due to their different ranges of values. The $\mathrm{pH}$ ranges from 4.26 to 6.62 , and the mean of 5.16 which is lower than the WHO range of 6.5-8.5 (WHO 2012). The spatial variation map of $\mathrm{pH}$ (Fig. 2n) indicates relatively low $\mathrm{pH}$ in the southern part of the study area. According to Agyemang (2019), the observed generally low $\mathrm{pH}$ may be as a result of carbonic acid produced from dissolved carbon dioxide in the groundwater. The southern part of the study area is underlain by granitoids of the Birimian which has distinct hydrochemical characteristics from that of the Voltaian that is found in the northern part (Fig. 1). The EC range of $93.33-700.28 \mu \mathrm{S} / \mathrm{cm}$ is lower than the WHO (2012) value of $1000 \mu \mathrm{S} / \mathrm{cm}$ just as the TDS range of $56.00-420.17 \mathrm{mg} / \mathrm{l}$ is lower than $1500 \mathrm{mg} / \mathrm{l}$. The low EC and TDS values reveal that the hydrochemistry of the groundwater is generally controlled by natural processes. The $\mathrm{TH}$ concentration ranges between $12.00 \mathrm{mg} / \mathrm{l}$ and $272.00 \mathrm{mg} / \mathrm{l}$ below the WHO value of $500.00 \mathrm{mg} / \mathrm{l}$. The map of TH (Fig. 2q) indicates generally low values except for a few localities. The range of concentrations of $\mathrm{Ca}^{2+}$ and $\mathrm{Mg}^{2+}$ are $0.06-36.46 \mathrm{mg} / \mathrm{l}$ and $0.02-17.75 \mathrm{mg} / \mathrm{l}$ below their respective WHO (2012) values of $75.00 \mathrm{mg} / 1$ and $150.00 \mathrm{mg} / \mathrm{l}$. Generally, the maps of $\mathrm{Ca}^{2+}$ and $\mathrm{Mg}^{2+}$ indicated low concentrations, while relatively high values were recorded at localities within the Voltaian Supergroup.

The range of $\mathrm{Na}^{+}$is $12.20-60.90 \mathrm{mg} / \mathrm{l}$ and it is less than the recommended value of $200.00 \mathrm{mg} / \mathrm{l}$. Similarly, the range of $\mathrm{Cl}^{-}$is $5.22-170.72 \mathrm{mg} / \mathrm{l}$ and it is below the WHO (2012) value of $250.00 \mathrm{mg} / \mathrm{l}$. The spatial variation map of $\mathrm{Na}^{+}$shows that the concentration is high in selected communities within the southern part which serves as the discharge area and is underlain by the Birimian granitoid (Yidana et al. 2015). It is worth noted that the spatial distribution of $\mathrm{Cl}^{-}$and $\mathrm{Na}^{+}$follow a similar pattern in the study (Fig. 2b, j). This observation confirms the presence of Na-Cl water type in the study area (Agyemang 2019). Also, the maps reveal that the relatively high concentrations are associated with Birimian granitoid which influences the geochemistry of the groundwater through geogenic processes like rock weathering and ion exchange. $\mathrm{HCO}_{3}{ }^{-}$map shows generally low concentrations within 
Table 1 Statistical summary of the groundwater data

\begin{tabular}{|c|c|c|c|c|c|c|}
\hline Parameter & Unit & Minimum & Maximum & Mean & Std. Deviation & WHO (2012) \\
\hline TDS & $\mathrm{mg} / \mathrm{l}$ & 56.00 & 420.17 & 159.45 & 95.17 & 1500.00 \\
\hline EC & $\mu \mathrm{S} / \mathrm{cm}$ & 93.33 & 700.28 & 265.75 & 158.61 & 1000.00 \\
\hline Temp & ${ }^{\circ} \mathrm{c}$ & 23.00 & 33.00 & 29.47 & 1.65 & 15.00 \\
\hline $\mathrm{pH}$ & $\mathrm{pH}$ unit & 4.26 & 6.62 & 5.16 & 0.54 & $6.5-8.5$ \\
\hline $\mathrm{Fe}$ & $\mathrm{mg} / \mathrm{l}$ & 0.00 & 13.26 & 0.35 & 2.10 & 0.30 \\
\hline $\mathrm{Zn}$ & $\mathrm{mg} / \mathrm{l}$ & 0.00 & 0.13 & 0.01 & 0.02 & 5.00 \\
\hline $\mathrm{Pb}$ & $\mathrm{mg} / \mathrm{l}$ & 0.00 & 0.36 & 0.03 & 0.07 & 0.01 \\
\hline $\mathrm{Cu}$ & $\mathrm{mg} / \mathrm{l}$ & 0.00 & 0.43 & 0.03 & 0.07 & 2.00 \\
\hline $\mathrm{Mn}$ & $\mathrm{mg} / \mathrm{l}$ & 0.00 & 0.21 & 0.07 & 0.06 & 0.10 \\
\hline $\mathrm{Cd}$ & $\mathrm{mg} / \mathrm{l}$ & 0.00 & 0.02 & 0.00 & 0.00 & 0.00 \\
\hline E. Coli & $\mathrm{CFU} / 100 \mathrm{ml}$ & 0.00 & 6.00 & 1.05 & 1.77 & 0.00 \\
\hline F. Coli & $\mathrm{CFU} / 100 \mathrm{ml}$ & 0.00 & 5.00 & 0.42 & 1.17 & 0.00 \\
\hline P. Coli & $\mathrm{CFU} / 100 \mathrm{ml}$ & 0.00 & 0.00 & 0.00 & 0.00 & 0.00 \\
\hline TSS & $\mathrm{mg} / \mathrm{l}$ & 0.00 & 20.00 & 1.10 & 3.26 & 500.00 \\
\hline Turbidity & $\mathrm{mg} / \mathrm{l}$ & 0.00 & 7.00 & 0.78 & 1.48 & 5.00 \\
\hline Salinity & $\mathrm{mg} / \mathrm{l}$ & 0.00 & 7.10 & 0.27 & 1.11 & 1000.00 \\
\hline Color & PCU & 0.00 & 4.00 & 0.50 & 0.91 & 15.00 \\
\hline $\mathrm{F}^{-}$ & $\mathrm{mg} / \mathrm{l}$ & 0.00 & 2.26 & 0.15 & 0.47 & 1.50 \\
\hline $\mathrm{TH}$ & $\mathrm{mg} / \mathrm{l}$ & 12.00 & 272.00 & 67.60 & 76.89 & 500.00 \\
\hline $\mathrm{Br}^{-}$ & $\mathrm{mg} / \mathrm{l}$ & 0.00 & 0.10 & 0.01 & 0.02 & 0.01 \\
\hline $\mathrm{PO}_{4}^{3-}$ & $\mathrm{mg} / \mathrm{l}$ & 0.01 & 3.06 & 0.25 & 0.52 & 0.10 \\
\hline DO & - & 9.14 & 21.13 & 15.17 & 2.61 & - \\
\hline BODS & - & 5.35 & 16.05 & 10.21 & 2.16 & - \\
\hline $\mathrm{Ca}^{2+}$ & $\mathrm{mg} / \mathrm{l}$ & 0.06 & 36.46 & 3.92 & 6.78 & 75.00 \\
\hline $\mathrm{Mg}^{2+}$ & $\mathrm{mg} / \mathrm{l}$ & 0.02 & 17.75 & 3.24 & 3.91 & 150.00 \\
\hline $\mathrm{Na}^{+}$ & $\mathrm{mg} / \mathrm{l}$ & 12.20 & 60.90 & 30.10 & 14.09 & 200.00 \\
\hline $\mathrm{K}^{+}$ & $\mathrm{mg} / \mathrm{l}$ & 4.00 & 154.00 & 18.70 & 27.02 & 30.00 \\
\hline $\mathrm{HCO}_{3}^{-}$ & $\mathrm{mg} / \mathrm{l}$ & 9.53 & 270.66 & 50.38 & 46.40 & \\
\hline $\mathrm{Cl}^{-}$ & $\mathrm{mg} / \mathrm{l}$ & 5.22 & 170.72 & 51.80 & 39.02 & 250.00 \\
\hline $\mathrm{SO}_{4}{ }^{2-}$ & $\mathrm{mg} / \mathrm{l}$ & 0.05 & 10.49 & 1.32 & 1.78 & 250.00 \\
\hline $\mathrm{NO}_{3}^{-}$ & $\mathrm{mg} / \mathrm{l}$ & 0.01 & 2.94 & 0.44 & 0.69 & 50.00 \\
\hline
\end{tabular}

the area. The concentrations in the Birimian granitoid are higher than that of the Voltaian Supergroup. The ranges of $\mathrm{SO}_{4}{ }^{2-}$ and $\mathrm{NO}_{3}{ }^{-}$concentrations are $0.05-10.49 \mathrm{mg} / \mathrm{l}$ and 0.01-2.94 $\mathrm{mg} / \mathrm{l}$ which below their respective WHO values of $250 \mathrm{mg} / \mathrm{l}$ and $50 \mathrm{mg} / \mathrm{l}$. The map of $\mathrm{SO}_{4}{ }^{2-}$ shows the highest concentration at a locality within the northern part (Fig. 2o). This observation is attributed to local anthropogenic activities such as improper waste disposal and application of agrochemicals. The concentration of $\mathrm{NO}_{3}{ }^{-}$in the area is generally low. The relatively high concentrations of $\mathrm{NO}_{3}{ }^{-}$are associated with selected localities within the central part due to the impact of local human activities (Fig. 2k). The presence of fecal coliform and Escherichia coliform (Fig. 2f, r) in the groundwater confirms the impact of the anthropogenic activities on the groundwater since the presence of fecal coliform indicates fecal contamination of the groundwater (Leclerc et al. 2001). The ranges of fecal coliform and Escherichia coliform are
0-6 CFU/100 $\mathrm{ml}$ and 0-5 CFU/100 $\mathrm{ml}$, respectively, while WHO (2012) recommends their total absence in drinking water. The study revealed that even though some of the boreholes samples for this study had fecal coliform and Escherichia coliform contamination none of them showed pathogenic coliform contamination (Table 1).

\section{Principal component analysis}

The identification of similarities and dissimilarities of the various parameters which reveal the possible pollution sources was done by the application of Factor Analysis. The application of the Varimax rotation method resulted in the records of the variance in Table 2. The Eigenvalues together with the Eigenvectors were assessed and the data was transformed into factors (components). Seven components contain $81.01 \%$ of the variation of the original variables. Table 3 shows the rotated component matrix of the 


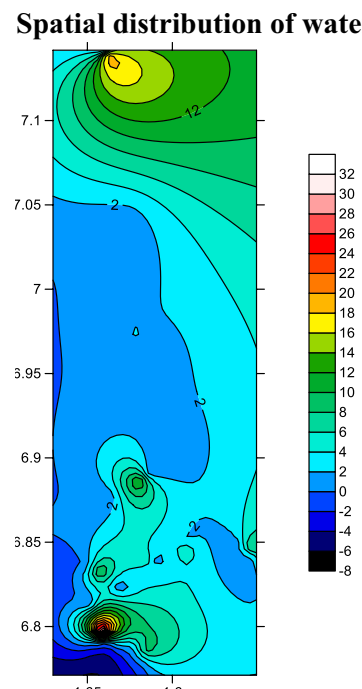

(a) $\mathrm{Ca}^{2+}$

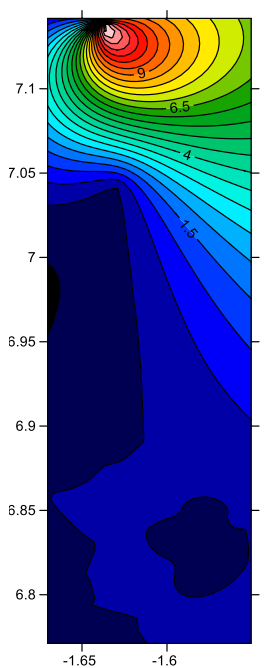

(e) $\mathrm{Fe}$

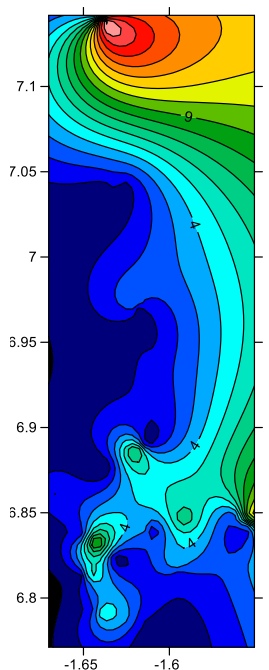

(i) $\mathrm{Mg}^{2+}$

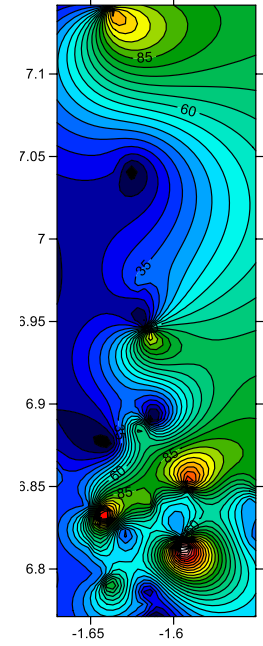

(b) $\mathrm{Cl}^{-}$

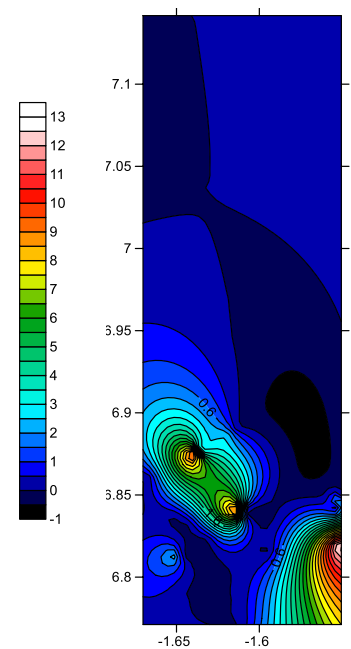

(f) Fecal Coliform

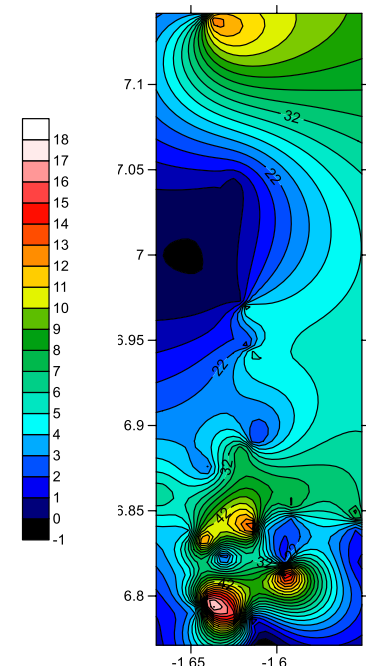

(j) $\mathrm{Na}^{+}$

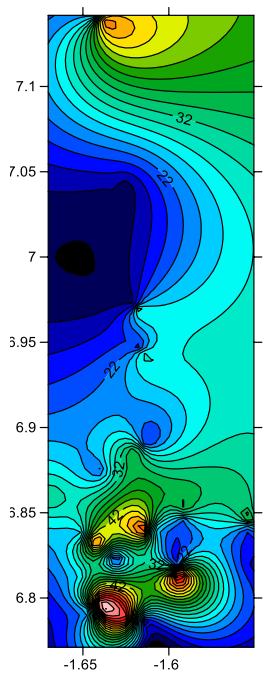

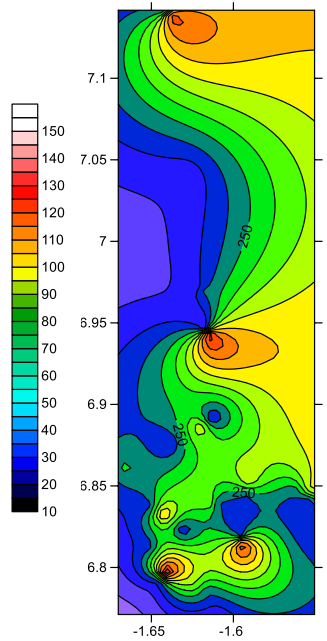

(c) $\mathrm{EC}$

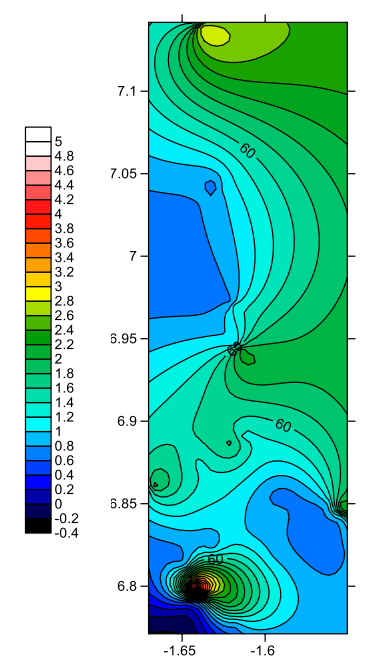

(g) $\mathrm{HCO}_{3}^{-}$

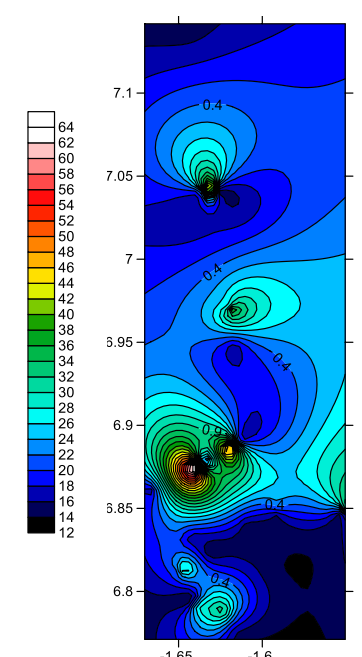

(k) $\mathrm{NO}_{3}^{-1.6}$

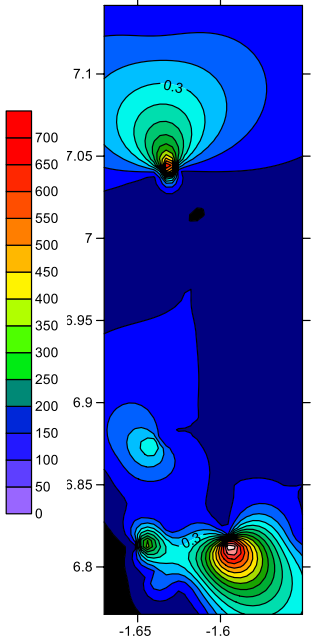

(d) $\mathrm{F}^{-}$

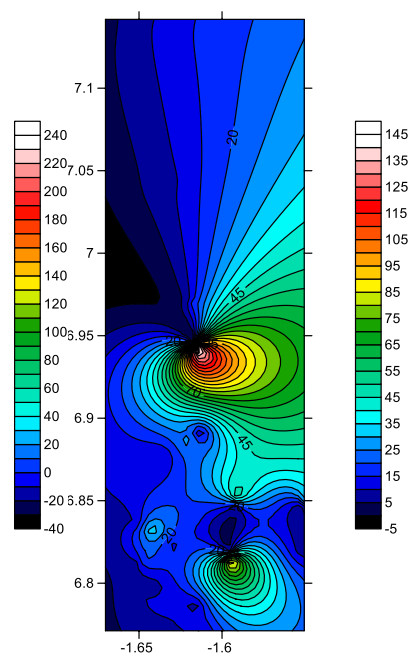

(h) $\mathrm{K}^{+}$

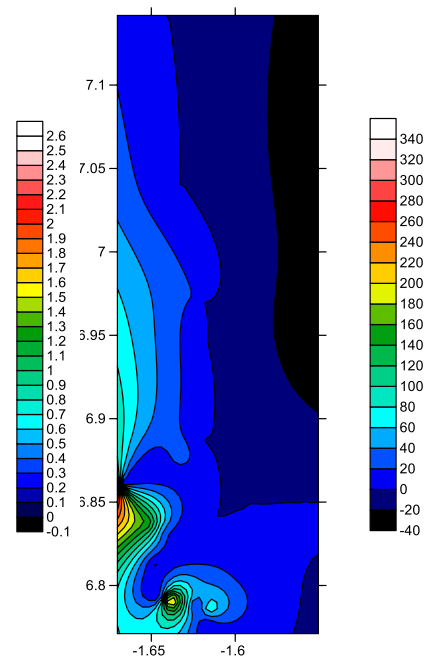

(l) $\mathrm{Pb}$

Fig. 2 a-r: Thematic maps of selected groundwater quality parameters in the study area 


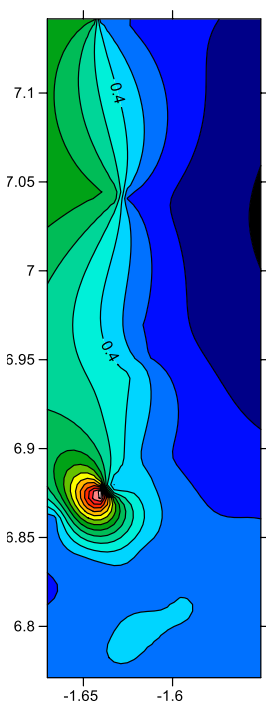

(m) $\mathrm{PO}_{4}^{3-}$

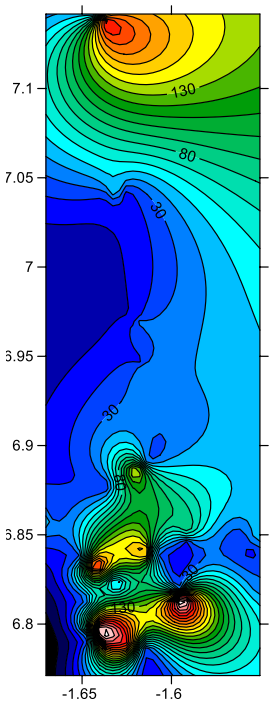

(q) $\mathrm{TH}$

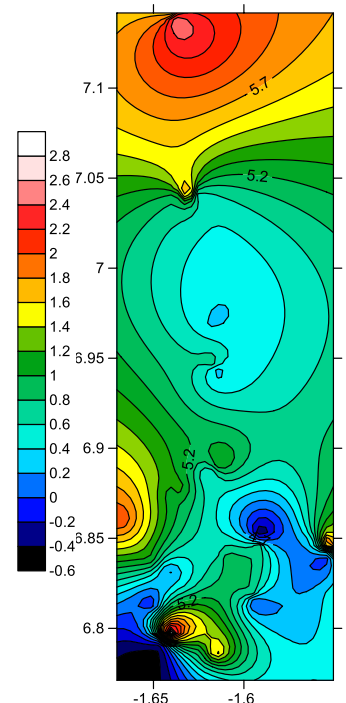

(n) $\mathrm{pH}$

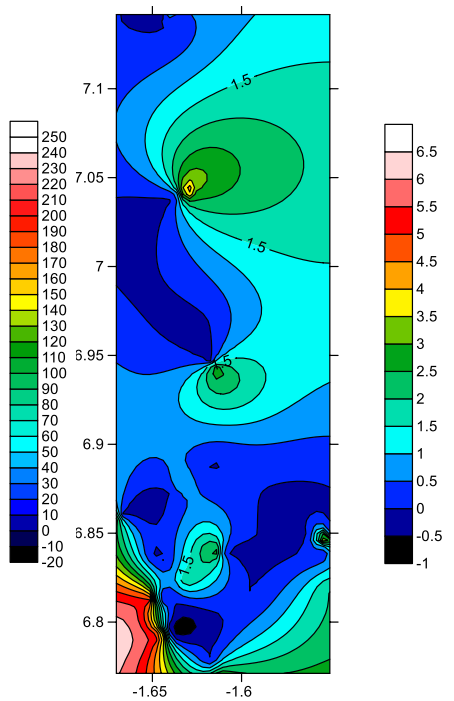

(r) Total Coliform

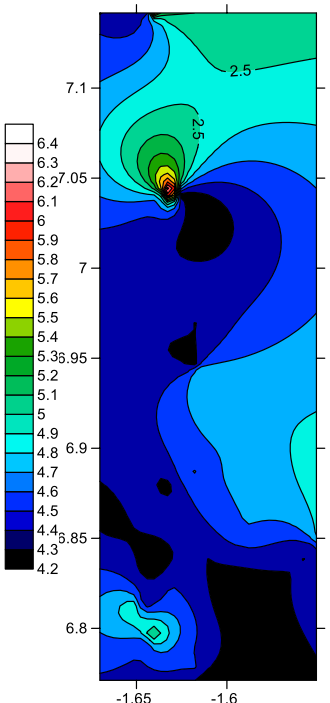

(o) $\mathrm{SO}_{4}{ }^{2-1}$

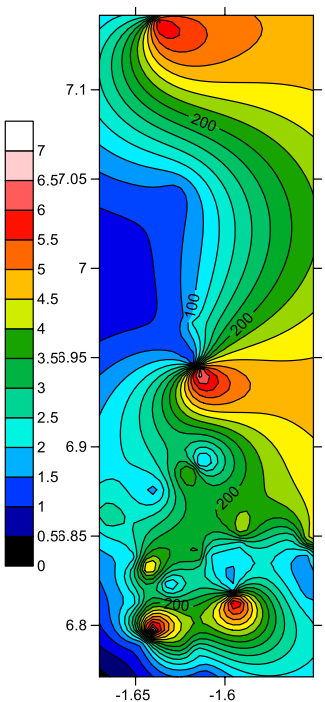

(p) TDS

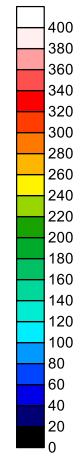

Fig. 2 (continued)

Table 2 Total variance and cumulative percentage of components

\begin{tabular}{|c|c|c|c|c|c|c|c|c|c|}
\hline \multirow[t]{2}{*}{ Component } & \multicolumn{3}{|c|}{ Initial eigenvalues } & \multicolumn{3}{|c|}{ Extraction sums of squared loadings } & \multicolumn{3}{|c|}{ Rotation sums of squared loadings } \\
\hline & Total & $\%$ of variance & Cumulative $\%$ & Total & $\%$ of variance & Cumulative $\%$ & Total & $\%$ of variance & Cumulative $\%$ \\
\hline 1 & 6.267 & 32.987 & 32.987 & 6.267 & 32.987 & 32.987 & 5.954 & 31.336 & 31.336 \\
\hline 2 & 2.392 & 12.589 & 45.575 & 2.392 & 12.589 & 45.575 & 2.085 & 10.974 & 42.310 \\
\hline 3 & 1.943 & 10.229 & 55.804 & 1.943 & 10.229 & 55.804 & 1.598 & 8.409 & 50.719 \\
\hline 4 & 1.414 & 7.445 & 63.249 & 1.414 & 7.445 & 63.249 & 1.556 & 8.190 & 58.909 \\
\hline 5 & 1.324 & 6.967 & 70.215 & 1.324 & 6.967 & 70.215 & 1.545 & 8.134 & 67.043 \\
\hline 6 & 1.033 & 5.438 & 75.653 & 1.033 & 5.438 & 75.653 & 1.474 & 7.756 & 74.799 \\
\hline 7 & 1.018 & 5.357 & 81.010 & 1.018 & 5.357 & 81.010 & 1.180 & 6.211 & 81.010 \\
\hline
\end{tabular}


Table 3 Rotated component matrix

Fig. 3 Scree plot showing the Eigenvalues of the various components

\begin{tabular}{|c|c|c|c|c|c|c|c|}
\hline & \multicolumn{7}{|c|}{ Component } \\
\hline & 1 & 2 & 3 & 4 & 5 & 6 & 7 \\
\hline TDS & 0.937 & 0.109 & -0.164 & -0.014 & -0.062 & -0.003 & -0.115 \\
\hline $\mathrm{PH}$ & 0.089 & 0.911 & 0.082 & 0.104 & 0.130 & 0.051 & -0.052 \\
\hline E. Coli & -0.057 & -0.014 & 0.772 & -0.026 & -0.157 & 0.053 & 0.204 \\
\hline F. Coli & -0.025 & -0.029 & 0.044 & -0.063 & 0.136 & 0.035 & 0.904 \\
\hline Salinity & -0.530 & -0.051 & 0.296 & 0.217 & 0.560 & -0.160 & -0.058 \\
\hline $\mathrm{F}^{-}$ & 0.133 & -0.143 & 0.182 & -0.444 & 0.598 & 0.100 & 0.314 \\
\hline $\mathrm{TH}$ & 0.880 & 0.138 & 0.013 & -0.138 & 0.203 & 0.014 & 0.047 \\
\hline $\mathrm{Br}^{-}$ & -0.314 & -0.004 & 0.729 & -0.276 & 0.233 & -0.023 & -0.292 \\
\hline $\mathrm{PO}_{4}{ }^{3-}$ & 0.004 & 0.092 & -0.170 & 0.015 & 0.797 & 0.148 & 0.069 \\
\hline DO & -0.109 & 0.123 & -0.123 & 0.835 & -0.004 & 0.015 & -0.055 \\
\hline $\mathrm{Ca}^{2+}$ & 0.709 & 0.177 & -0.017 & 0.476 & 0.038 & -0.048 & 0.066 \\
\hline $\mathrm{Mg}^{2+}$ & 0.759 & 0.005 & 0.039 & 0.348 & -0.118 & 0.302 & 0.030 \\
\hline $\mathrm{Na}^{+}$ & 0.905 & 0.135 & -0.189 & -0.190 & -0.093 & 0.014 & 0.034 \\
\hline $\mathrm{K}^{+}$ & 0.500 & -0.549 & -0.151 & -0.259 & 0.065 & 0.000 & -0.236 \\
\hline $\mathrm{HCO}_{3}^{-}$ & 0.388 & 0.745 & -0.283 & 0.038 & -0.141 & -0.053 & -0.090 \\
\hline $\mathrm{Cl}^{-}$ & 0.859 & -0.373 & -0.011 & 0.084 & -0.070 & 0.033 & -0.058 \\
\hline $\mathrm{SO}_{4}^{2-}$ & 0.158 & 0.277 & 0.299 & 0.043 & 0.008 & 0.771 & -0.111 \\
\hline $\mathrm{NO}_{3}^{-}$ & 0.013 & -0.197 & -0.176 & -0.041 & 0.163 & 0.843 & 0.146 \\
\hline $\mathrm{SIO}_{2}$ & 0.905 & 0.124 & -0.088 & -0.203 & -0.010 & 0.076 & 0.027 \\
\hline
\end{tabular}

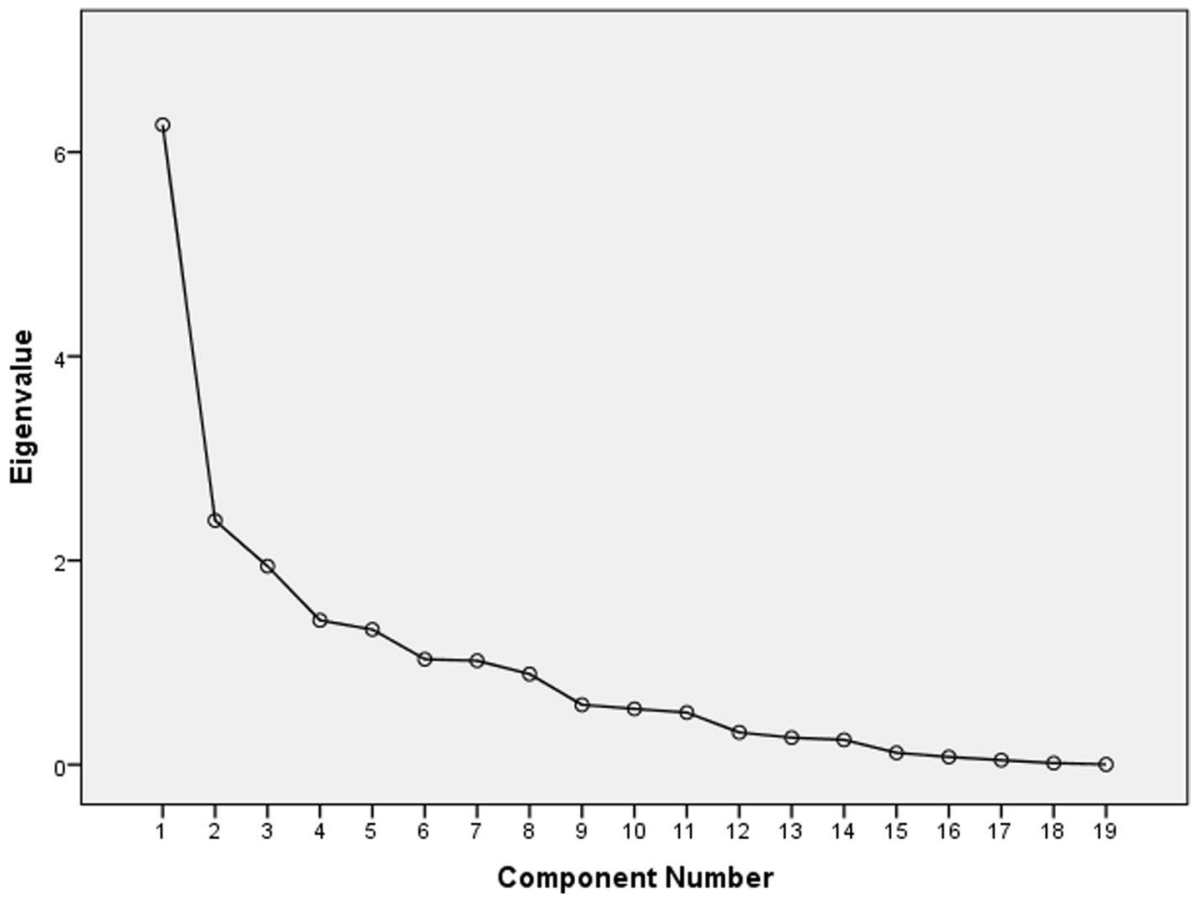

seven components that together show $81.01 \%$ of the total variance and have Eigenvalues greater than one (Fig. 3). The plot of the various components in the rotated space in Fig. 4 shows how close the various variables of the components are to each other in the 3-dimensional sample space.
Factor one shows $31.34 \%$ variance and high positive loading of TDS, $\mathrm{SiO}_{2}, \mathrm{Ca}^{2+}, \mathrm{Mg}^{2+}, \mathrm{Na}^{+}, \mathrm{TH}, \mathrm{K}^{+}, \mathrm{Cl}^{-}$and negative loading of salinity which indicates a high concentration of ions, influenced by a similar source. The high loading of TDS is due to the active participation of 


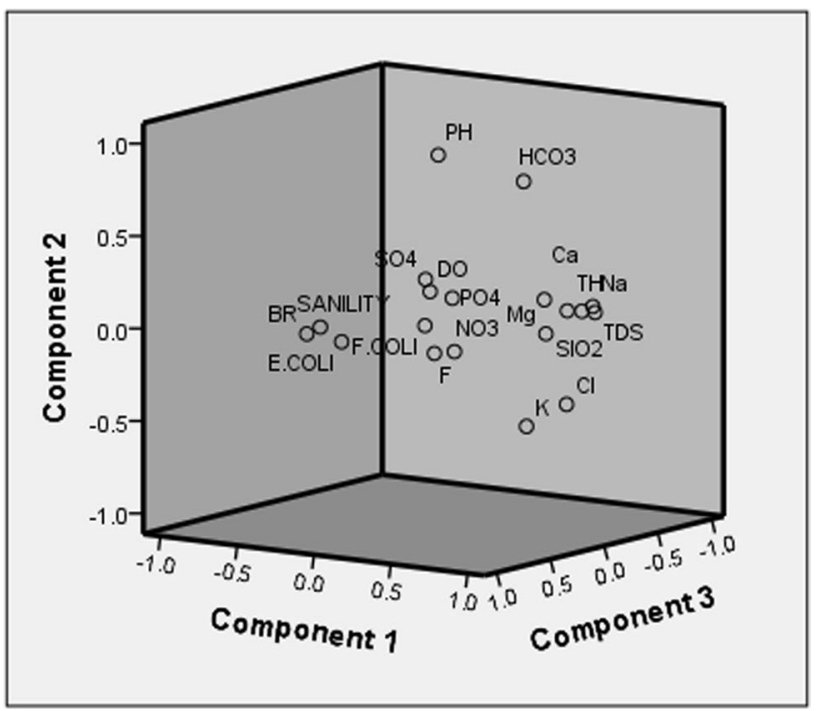

Fig. 4 Plot of components in rotated space to show their spatial relations

dissolved ions in the groundwater quality. The major variables constituting $\left(\mathrm{Ca}^{2+}, \mathrm{Mg}^{2+}, \mathrm{SiO}_{2}, \mathrm{Na}^{+}\right)$is related to the hydrochemical variables originating from the mineralization of groundwater. Enrichment of both $\mathrm{Na}^{+}$and $\mathrm{Cl}^{-}$is also possibly related to urban wastewaters. The impact of agricultural activities and weathering of K-feldspar from surrounding geology may account for the high loading for $\mathrm{K}^{+}$. Positive loadings of $\mathrm{pH}, \mathrm{HCO}_{3}{ }^{-}$and negative loading of $\mathrm{K}^{+}$in Factor 2 accounts for $10.97 \%$ of the total variance. Bicarbonate mainly originates from the dissolution of carbonate rocks and $\mathrm{CO}_{2}$. The high negative loading of $\mathrm{K}^{+}$suggests the impact of fertilizer application, improper waste disposal on the groundwater quality. The third and fourth factors explain $8.41 \%$ and $8.19 \%$ of the variances and are composed of positive loadings of $\mathrm{Br}^{-}$, E. coli and DO, respectively. The association of $\mathrm{Br}^{-}$, E. coli and DO indicates the effect of environmental factors and anthropogenic activities on the groundwater quality. The fifth factor shows $8.13 \%$ variance and it is made up of positive loading of salinity, $\mathrm{F}^{-}$, and $\mathrm{PO}_{4}{ }^{3-}$. This presents the impacts of improper waste disposal and poor hygienic conditions around the boreholes on the groundwater quality. Components 6 and 7 contain $\mathrm{SO}_{4}{ }^{2-}, \mathrm{NO}_{3}{ }^{-}$and $\mathrm{F}$. coli and show $7.76 \%$ and $6.21 \%$ variances, respectively. These show the impacts of improper waste disposal, the use of pit latrine, poor hygienic conditions around the borehole locations (which are common in the study area) on the groundwater quality.
Fig. 5 Dendrogram showing the clustering of groundwater parameters

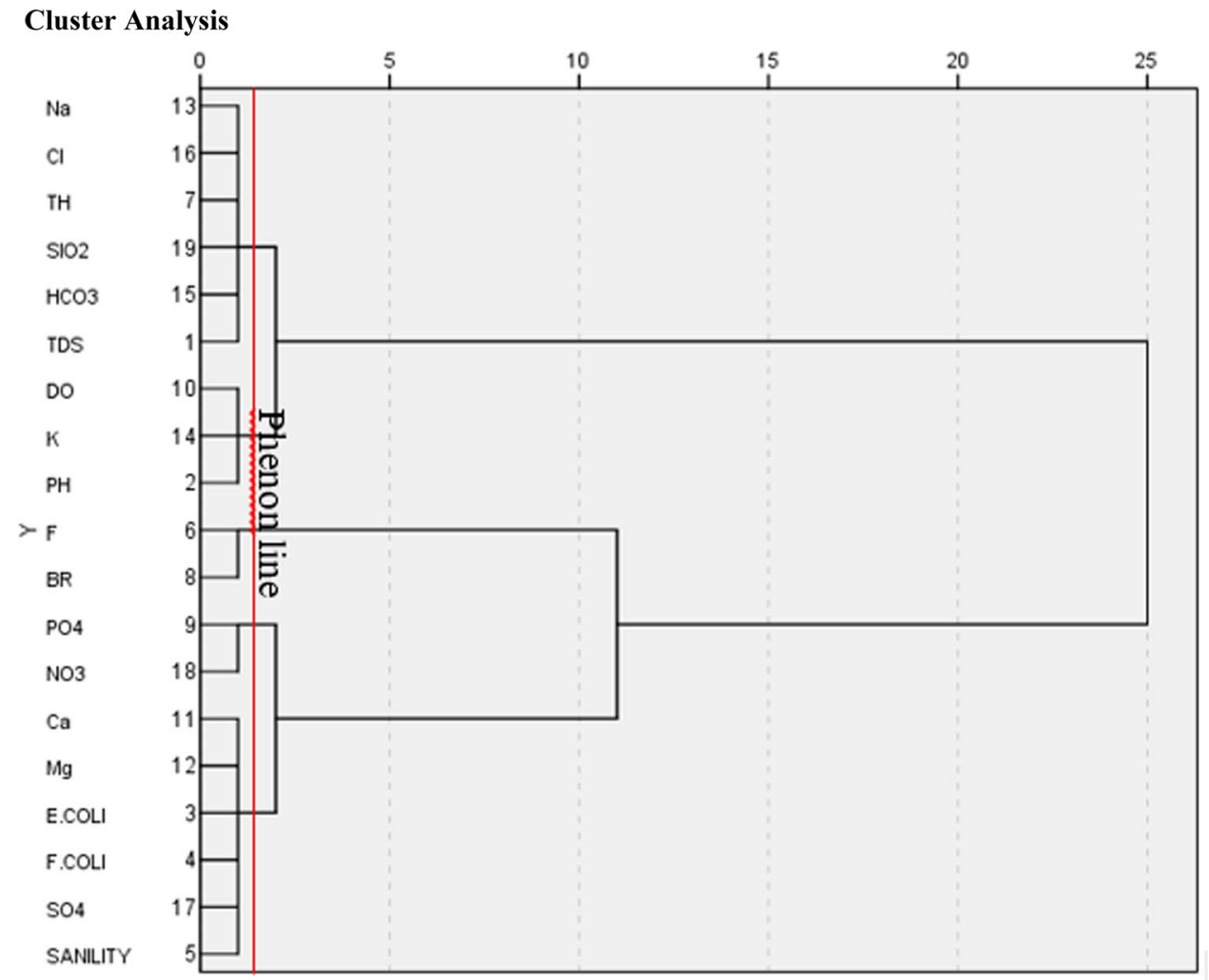




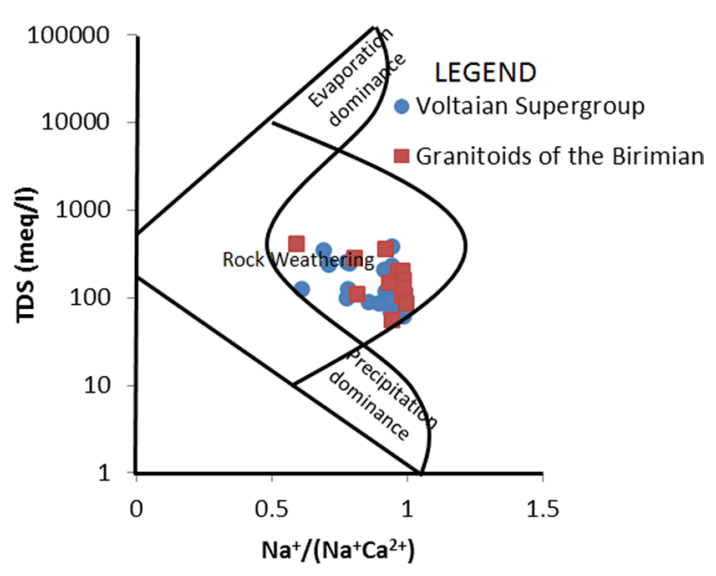

Fig. 6 A plot of TDS versus $\mathrm{Na}+/(\mathrm{Na}++\mathrm{Ca} 2+)$ of groundwater of the study area

\section{Cluster analysis}

The study implored R-mode cluster analysis to show relationships between variables and the data were normalized before clustering. The dendrogram (Fig. 5) shows five clusters that reflect possible strong mutual correlations that exist among the parameters. The grouping of $\mathrm{Na}^{+}, \mathrm{Cl}^{-}, \mathrm{TH}, \mathrm{SiO}_{2}$, $\mathrm{HCO}_{3}{ }^{-}$and TDS together in cluster 1 suggests the impacts of rock weathering and anthropogenic activities on groundwater quality. $\mathrm{SiO}_{2}$ and $\mathrm{HCO}_{3}^{-}$represent silicate weathering while the loading of $\mathrm{Na}^{+}, \mathrm{Cl}^{-}, \mathrm{TH}$, and TDS suggests influence from anthropogenic activities. Cluster 2 and cluster 3 contain dissolved oxygen (DO), $\mathrm{pH}, \mathrm{K}^{+}$and $\mathrm{F}^{-}, \mathrm{Br}$, respectively. This observation indicates contamination of the groundwater by activities such as improper waste disposal. Cluster 4 is made of $\mathrm{PO}_{4}{ }^{3-}$ and $\mathrm{NO}_{3}{ }^{-}$and this suggests the impact of agrochemicals and animal manure on farmlands on the groundwater quality (Koh et al. 2010). Cluster 5 has $\mathrm{Ca}^{2+}, \mathrm{Mg}^{2+}$, E. coli, F. coli, $\mathrm{SO}_{4}{ }^{2-}$, and salinity. The observed association of E. coli, F. coli, $\mathrm{SO}_{4}{ }^{2-}$, and salinity is due to the impacts of anthropogenic activities such as improper waste disposal, the use of pit latrine, poor hygienic conditions around the borehole locations on the groundwater quality. Clustering of $\mathrm{Ca}^{2+}$ and $\mathrm{Mg}^{2+}$ shows rock minerals dissolution or by an ion exchange process.

\section{Correlation analysis}

The use of correlation analysis in groundwater studies to uncover the relationship between various parameters to show their source and pathways is reported in many works of literature (Varol and Davraz 2014; Hussain 2019; McGrorya 2020). In this study, the correlations between the various parameters are shown in Table 4 . The study revealed that EC shows positive correlation with TDS (0.97), $\mathrm{Mg}^{2+}$ (0.70), $\mathrm{Ca}^{2+}(0.72), \mathrm{Mn}(0.58), \mathrm{Na}^{+}(0.849)$, TH (0.84), $\mathrm{HCO}_{3}^{-}$(0.52). The positive correlation of EC with the above-mentioned parameters shows how their concentrations affect the EC of the groundwater. This indicates that the dissolution of rock minerals which control the concentrations of $\mathrm{Mg}^{2+}, \mathrm{Ca}^{2+}, \mathrm{Mn}, \mathrm{Na}^{+}, \mathrm{TH}, \mathrm{HCO}_{3}^{-}$influences the geochemistry of the groundwater and indirectly affects the EC and the TDS of the groundwater. The $\mathrm{pH}$ of the groundwater is generally low which indicates the slightly acidic nature of the groundwater. This observation is influenced by the concentrations of the $\mathrm{Ca}^{2+}$ and $\mathrm{HCO}_{3}{ }^{-}$as the $\mathrm{pH}$ shows a positive correlation with $\mathrm{Ca}^{2+}(0.51), \mathrm{HCO}_{3}^{-}(0.79) . \mathrm{Mg}^{2+}$ shows positive correlation with $\mathrm{Ca}^{2+}(0.543), \mathrm{Na}^{+}(0.54)$, $\mathrm{TH}(0.50), \mathrm{HCO}_{3}{ }^{-}(0.51)$ and $\mathrm{Fe}(0.629)$. This observation indicates that the concentrations of the above parameters in the groundwater are influenced by similar processes such
Fig. 7 A plot of

$(\mathrm{Ca} 2++\mathrm{Mg} 2+)$ vs. $\mathrm{TZ}+$ of groundwater of the study area

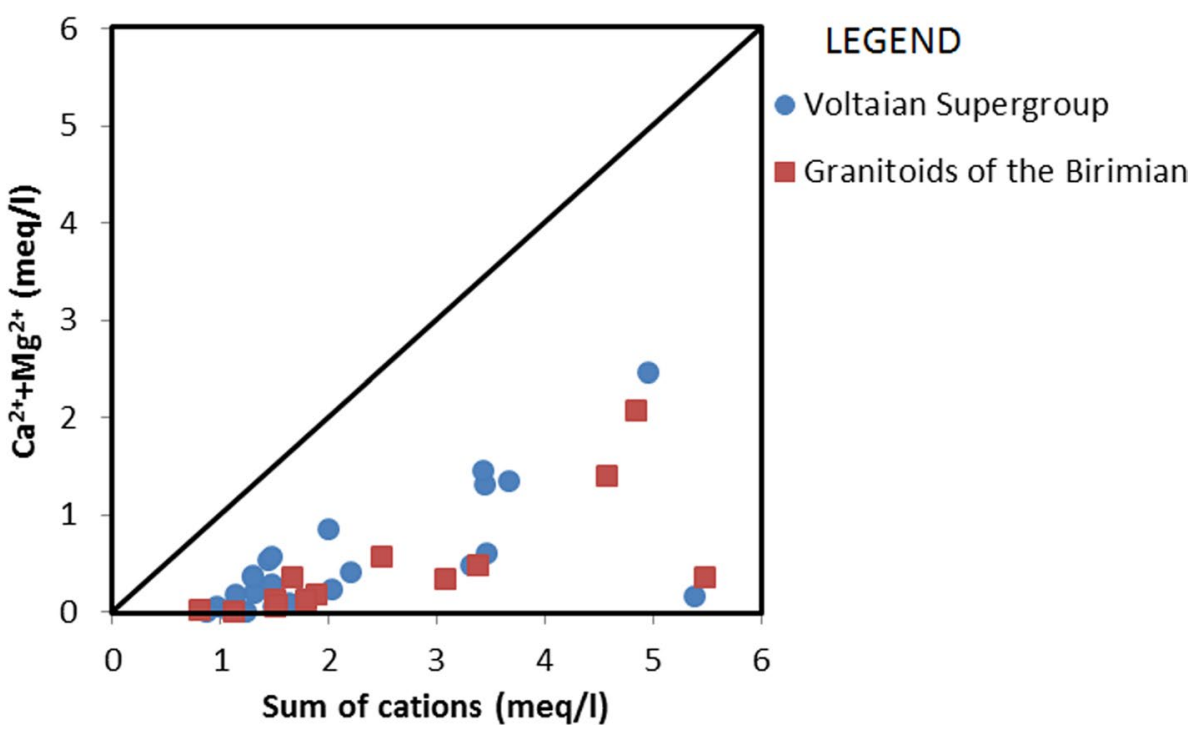




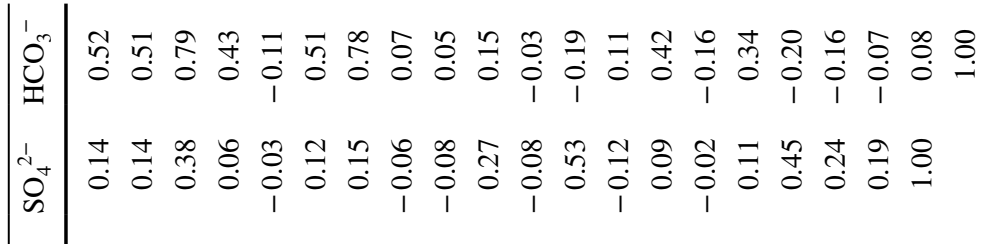

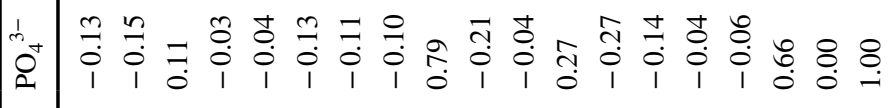

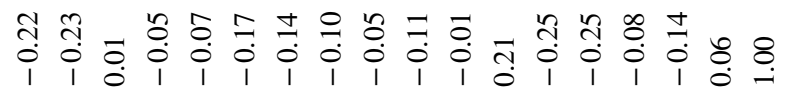

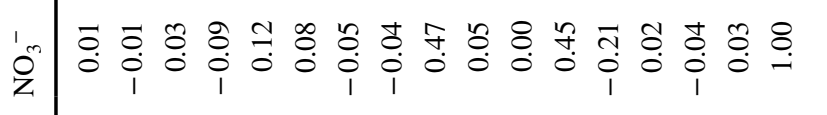

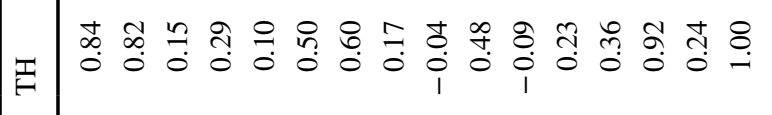

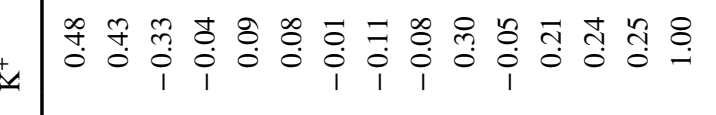

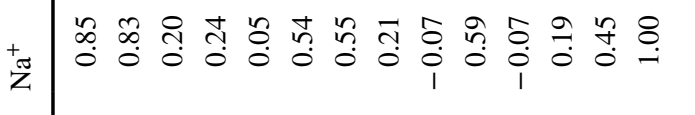

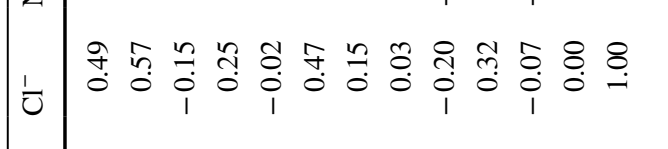

$$
\begin{aligned}
& \text { I }
\end{aligned}
$$

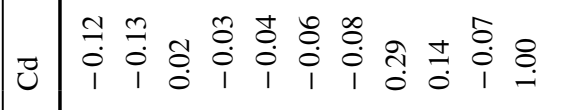

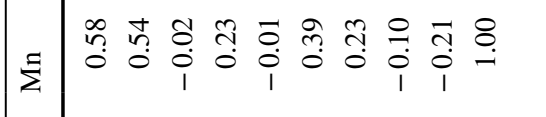

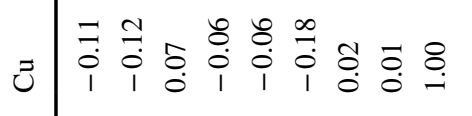

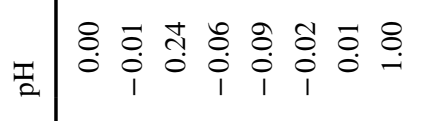

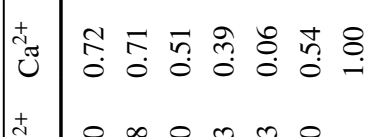

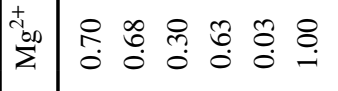

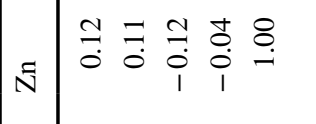

$$
\begin{aligned}
& \text { 幽 } \\
& \text { चี }
\end{aligned}
$$

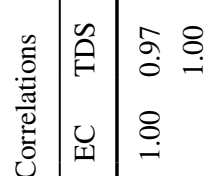

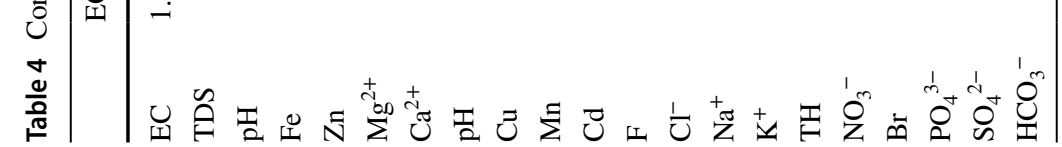


as rock mineral dissolution and ion exchange. The observation of the positive correlation between $\mathrm{Ca}^{2+}$ and $\mathrm{Na}^{+}$ (0.55), $\mathrm{TH}(0.50)$, as well as $\mathrm{HCO}_{3}{ }^{-}(0.78)$ reveals the possible occurrence of ion exchange in the groundwater. The positive correlations between $\mathrm{Cu}$ and $\mathrm{PO}_{4}{ }^{3-}(0.79), \mathrm{Mn}$ and $\mathrm{Na}^{+}(0.59), \mathrm{F}^{-}$and $\mathrm{SO}_{4}{ }^{2-}(0.53)$ as well as $\mathrm{NO}_{3}{ }^{-}$and $\mathrm{PO}_{4}{ }^{3-}(0.66)$ reveal the possible impact of anthropogenic activities such as improper waste disposal, application of agrochemicals, lack of proper hygiene around point sources on the groundwater geochemistry. It is important to mention here that in this study, the Principal Component Analysis, the Cluster Analysis, and the Correlation Analysis revealed similar results.

\section{Hydrogeological processes}

To understand the effects of precipitation, rock weathering and evaporation on groundwater geochemistry Gibbs (1970) proposed a diagram (Fig. 6). The diagram has three sections of which each one represents the impact of one of these factors on the hydrochemistry of the groundwater. The impact of precipitation on the hydrochemistry is associated with low TDS and high $\mathrm{Na}^{+} /\left(\mathrm{Na}^{+}+\mathrm{Ca}^{2+}\right)$ weight ratio, rock dominance region is associated with moderate TDS and moderate $\mathrm{Na}^{+} /\left(\mathrm{Na}^{+}+\mathrm{Ca}^{2+}\right)$ ratio while the impact of evaporation is associated with high TDS and high $\mathrm{Na}^{+} /\left(\mathrm{Na}^{+}+\mathrm{Ca}^{2+}\right)$ ratio. In this study, the samples were characterized by moderate TDS and moderate $\mathrm{Na}^{+} /\left(\mathrm{Na}^{+}+\mathrm{Ca}^{2+}\right)$ ratio. Therefore, the samples plot within the rock dominance portion of the diagram, indicating that the major factor affecting the hydrochemistry of the groundwater is the rock weathering. Again, the plot of $\left(\mathrm{Ca}^{2+}+\mathrm{Mg}^{2+}\right)$ vs. Total cations (TZ) (Fig. 7) shows the data fall below the equiline line. This indicates an increasing contribution of alkalis to the major ions, hence; suggesting that silicate weathering is an important process occurring in the study area. An example of silicate weathering is given by Eq. (1).

$$
\begin{aligned}
& 2 \mathrm{NaAlSi}_{3} \mathrm{O}_{8}(\text { albite })+2 \mathrm{H}_{2} \mathrm{CO}_{3}+9 \mathrm{H}_{2} \mathrm{O} \\
& =\mathrm{Al}_{2} \mathrm{Si}_{2} \mathrm{O}_{5}(\mathrm{OH})_{4}(\text { kaolinite })+2 \mathrm{Na}^{+}+4 \mathrm{H}_{4} \mathrm{SiO}_{4}+2 \mathrm{HCO}_{3}^{-}
\end{aligned}
$$

\section{Conclusion}

The application of geostatistical techniques on groundwater data from the Afigya Kwabre District of Ghana has revealed that seven components contain $81.01 \%$ of the variation of the original variables. Factor 1 accounts for $31.34 \%$ of the total variance, factor 2 accounts for $10.97 \%$, third and fourth factors explain $8.41 \%$ and $8.19 \%$, the fifth factor shows $8.13 \%$ while the sixth and seventh components show $7.76 \%$ and $6.21 \%$ variances, respectively. Five clusters were identified. The study revealed that the geochemistry of the groundwater is influenced by rock mineral weathering, ion exchange, and anthropogenic activities such as application of agrochemicals on farmlands, improper waste disposal, etc. It has revealed that silicate weathering plays a major role in the groundwater geochemistry. Generally, the groundwater has low $\mathrm{pH}$. The groundwater in the District is generally suitable for domestic use with exception of a few samples with high $\mathrm{Fe}, \mathrm{F}^{-}$, $\mathrm{Pb}$ concentrations and Escherichia coliform and fecal coliform contaminations. The study has shown that the geostatistical technique is useful in determining the state of water contamination, the extent of contamination, and possible source of contaminants, as well as presenting a guideline for effective groundwater resource management.

Funding This study was funded by the author.

\section{Declarations}

Conflict of interest The author declares that he has no conflict of interest.

Open Access This article is licensed under a Creative Commons Attribution 4.0 International License, which permits use, sharing, adaptation, distribution and reproduction in any medium or format, as long as you give appropriate credit to the original author(s) and the source, provide a link to the Creative Commons licence, and indicate if changes were made. The images or other third party material in this article are included in the article's Creative Commons licence, unless indicated otherwise in a credit line to the material. If material is not included in the article's Creative Commons licence and your intended use is not permitted by statutory regulation or exceeds the permitted use, you will need to obtain permission directly from the copyright holder. To view a copy of this licence, visit http://creativecommons.org/licenses/by/4.0/.

\section{References}

Agyemang VO (2019) Hydrochemical assessment of groundwater quality for drinking, domestic and irrigation purposes in Afigya Kwabre district, Ghana. J Hydrogeol Hydrol Eng 8:3

America Public Health Association (1995) Standard methods for the examination of water and waste water, 19th edition, American Public Health Association Inc. Washington, DC

Celesceri L, Greenberg AE, Eaten AD (1998) Standard methods for the examination of water and waste water. American Public Health Association, Washington, $\mathrm{p} 134$

Community Water and Sanitation Agency (2018) Annual Report. Community Water and Sanitation Agency, Ghana. CWSA Head Office. Accra Ghana

Fadhillah MF, Lee S, Lee C-W, Park Y-C (2021) Application of support vector regression and metaheuristic optimization algorithms for groundwater potential mapping in Gangneung-si, South Korea. Remote Sens 13:1196. https://doi.org/10.3390/rs13061196

Ghana Statistical Services (2010) Population and housing census report. Ghana Statistical Service report 2010. GSS Head Office. Accra Ghana. 
Gibbs RJ (1970) Mechanisms controlling world water chemistry. Sci J 170:795-840

Hem JD (1985) Study and interpretation of the chemical characteristics of natural water. 3rd Edition. U.S. Geological Survey WaterSupply Paper 2254, pp. 263.

Hussain S, Habib-Ur-Rehman M, Khanam T, Sheer A, Kebin Z, Jianjun Y (2019) Health Risk Assessment of Different Heavy Metals Dissolved in Drinking Water. Int J Environ Res Public Health 16(10):1737. https://doi.org/10.3390/ijerph16101737

Kesse GO (1985) The mineral and rock resources of ghana. Balkema, Rotterdam, p 610

Koh DC, Mayer B, Lee KS, Ko KS (2010) Land-use controls on sources and fate of nitrate in shallow groundwater of an agricultural area revealed by multiple environmental tracers. J Contam Hydrol 118:62-78

Kortatsi B (2009) Groundwater quality in the Wassa west district of the western region of Ghana. West Afr J Appl Ecol. https://doi. org/10.4314/wajae.v11i1.45729

Leclerc H, Mossel DAA, Edberg SC, Struijk CB (2001) Advances in the bacteriology of the coliform group: their suitability as markers of microbial water safety. Annu Rev Microbiol 55:134-201

McGrorya E, Holianb E, Morrison L (2020) Assessment of groundwater processes using censored data analysis incorporating nondetect chemical, physical, and biological data. J Contam Hydrol 235:103706

National Groundwater Association News (2016) Groundwater 54(2):150-150

Nkrumah M (2005) Challenges to urban water management in Ghana: making public-private partnerships work. Ghana J Dev Stud. https://doi.org/10.4314/gjds.v1i2.35008

Obuobie E, Agyekum W, Appiah-Adjei EK, Upton K, Ó Dochartaigh BÉ (2016) Hydrogeology of Ghana. Hydrogeology of Ghana. British geological survey. Accessed [29/7/2017]. http:/ / earthwise. bgs. ac. uk/ index. php/ Hydrogeology of Ghana

Otto M (1998) Multivariate methods. In: Kellner R, Mermet JM, Otto M, Widmer HM (eds) Analytical chemistry. WileyeVCH, Weinheim
Patrick Asamoah Sakyi (2016) Activities such as navigation, transportation, hydroelectric power generation, and agricultural activities depend on water and in areas where surface water is scarce, some of these activities depend heavily on groundwater resources. Oral discussion, March 2016, Department of Earth Sciences, University of Ghana, Legon

Raju NJ (2007) Hydrogeochemical parameters for assessment of groundwater quality in the upper Gunjanaeru river basin, Cuddapah district, Andhra Pradesh, South India. Environ Geol 52:1067-1074

Varol S, Davraz A (2014) Evaluation of the groundwater quality with WQI (Water Quality Index) and multivariate analysis: a case study of the Tefenni plain (Burdur/Turkey). Environ Earth Sci. https:// doi.org/10.1007/s12665-014-3531-z

World Health Organization (2008) Guidelines for drinking-water quality: incorporating 1st and 2nd addenda, Vol. 1, Recommendations 9789241547611.

World Health Organization (2012) Edition of the drinking water standards and health advisories environmental protection agency 822 S-12-001 Washington, DC.

Yidana SM, Fynn OF, Chegbeleh LP, Loh Y, Obeng MA (2014) Analysis of recharge and groundwater flow in parts of a weathered aquifer system in Northern Ghana. J Appl Water Eng Res. https://doi. org/10.1080/23249676.2014.954009

Yidana SM, Essel SK, Addai MO, Fynn OF (2015) A preliminary analysis of the hydrogeological conditions and groundwater flow in some parts of a crystalline aquifer system: Afigya Sekyere South District, Ghana. J Afr Earth Sci 104:132-139

Publisher's Note Springer Nature remains neutral with regard to jurisdictional claims in published maps and institutional affiliations. 